\title{
Könyvtári közlemények
}

\author{
MH EK VEIG TKLI Tudományos Könyvtár
}

\section{„Tudományos Rendelő és Múzeum” a Magyar Néphadsereg Központi Kórházában}

\author{
Pogányné Dr. Rózsa Gabriella PhD
}

A II. világháború után az akkori Budapesti 1. számú Helyőrségi Kórház (a mai Magyar
Honvédség Egészségügyi Központ Róbert Károly körúti telephelye, Székhelye) újjáépítésének egyik területe volt az orvosi gyógyító és kutató munka támogatására megfelelő színvonalú orvosi tudományos könyvtár, illetve komplex információs szolgáltatásrendszer megteremtése. Az első intézkedések 1946 májusából származnak, amelyeket még számos további felterjesztés követett [1], a tudományos könyvtár struktúrája, illetve szervezeti helye tekintetében azonban sokáig nem született végleges döntés, így a központosított orvosi könyvtár és az „osztálykönyvtár” (sebészet, idegosztály, bőrosztály, belgyógyászat [2]) modell szerinti müködés váltotta egymást [3]. Mindeközben a könyvtár katalógusának elkészítése is „kalákában” történt, ahogyan ez az 1953. évi április 10-ei napiparancsban olvasható: „A kiosztott csoportbeosztási íveknek megfelelően az osztályok a szakkönyveket a kiadott minta szerint vegyék fel." [4], a szakrendes katalógus pedig Dr. Sántha András orvos ezredes munkája, aki ekkor a tudományos osztály vezetője volt [5]; és éppígy voltak a gyüjtemény(ek) kezelöi a Kórház további orvosai. Minden igyekezettel együtt azonban a könyvtár fejlődése nem volt elég tempós, megmutatkozott a szakképzett könyvtáros hiánya [6]. A személyzeti kérdés rendezésére bizonnyal több kísérlet is történt, ám ezek - még évekig - nem jártak sikerrel, az 1952/1953-as állománytábla sem tartalmazott könyvtárosi helyet [7]. Az ennek módosításával kapcsolatos egyik 1953-as jelentés a tudományos könyvtár személyi állományával is foglalkozik és önálló könyvtáros munkakör létesítését veti fel [8].

Mindezzel a stabilnak egyáltalán nem tekinthető személyzeti háttérrel a kórház orvosai mégis hozzájutottak orvosi könyvekhez, szakfolyóiratokhoz egyrészt mint a Honvédorvosi Közlemények (az 1950. évi 2. számtól Honvédorvos, 1953 és 1956 között Katonaorvosi Szemle) referátum-rovatának munkálataihoz, másrészt a Honvédelmi Minisztérium 529.823/Kfcs. X. 1948. számú rendelete alapján létrehozott dokumentációs szolgáltatás, „központi katonaegészségügyi irodalmi kartoték” elengedhetetlen előfeltételéhez [9].

Az orvosi könyvtár 1953. május 10-étől indította be „aktív folyóirat szolgáltatását”, vagyis a témafigyelést a kórház orvosai számára. Az osztályoktól bekért kutatási témáknak megfelelően „a könyvtárba érkezett új szakmai folyóiratokból felhívjuk az osztályok figyelmét az öket érdeklő cikkekre. Ez azonban semmi esetre sem jelenti azt, hogy az osztályok továbbra is ne foglalkozzanak önállóan anyagkereséssel, mivel sok esetben más irányú címü cikkben is találhatnak anyagot tudományos munkájukhoz." - olvasható a felhívás a kórház napiparancsában [10]. A témafigyelés beindításával a könyvtár a korabeli könyvtári szakmai elvárásoknak messzemenően megfelelt, szolgáltatási palettája naprakész volt - még ekkor is képzett könyvtáros nélkül. 
A kórházi, és szélesebb körben a katonaorvosi tudományos élet információs hátterének biztosítására alakította ki Dr. Vadász Gyula orvos alezredes, kórházparancsnok a Tudományos Rendelő és Múzeum koncepcióját 1951-ben. Az akkor még Tanulmányi Rendelő és Múzeum elnevezésű szervezeti egység személyi hátteréről már 1951 novemberében rendelkezett a parancsnok: alosztályvezetőként Dr. Vasvári Jenő orvos főhadnagyot rendelte, kollégája pedig egy laboráns és egy rajzoló lett [11]. Vasvári doktor 1953-ig volt a múzeum gondozója [12], 1953. november 12-étől pedig Dr. Birtalan Gyöző orvos föhadnagy [13], a későbbi jeles orvostörténész szakíró kapta meg e feladatot. A komplex tudományos szolgáltatás 1952. május 26-án indult útjára.

A szervezeti egység tevékenységével, feladataival kapcsolatban érdemes idézni az 1952. évi május 24-ei napiparancsból a vonatkozó parancspontot: „A Tudományos Rendelő és Múzeum felöleli a honvédorvosi szolgálat gazdag tapasztalatainak anyagát és annak irodalmát. Tárgya a kórházunkban előforduló ritka vagy tanulságos kóreseteknek és azok bibliografiájának gyüjtése, mely a honvédorvosi szolgálat fejlődését elősegíti. A kóresetek tisztázásához el kell végezni minden olyan vizsgálatot, ami fontos és szükséges a pontos kórismézéshez. A kórlapokat két példányban kell elkészíteni, fel kell szerelni Rtg., EKG, laboratóriumi, kórszövettani és stb. lelettel, esetleg fényképfelvétellel. A kórlap egyik példánya kerül a Múzeumba, a másik marad az osztályon. Ugyanakkor mellékelni kell az anyagra vonatkozó bibliográfiát is. A Múzeum ezt kartotékozza, rendszerbe gyüjti és az összegyült anyagot feldolgozza.

A Tudományos Rendelö és Múzeum felölel patologanatomiai preparátumokat, fényképeket, tanulmányokat, rajzokat, a gyakran előforduló betegségek statisztikai adatait és sok más katonai vonatkozású kiállítási tárgyakat és dokumentumokat.

A Múzeum mellett levéltár is lesz, mely magában foglalja: honv. orvosi intézmények beszámolóit, dokumentjeit, kórtörténeteket, folyóiratokat és más katonai anyagokat, melyeket tudományos feldolgozásnak kell alávetni.

A Tudományos Rendelő és Múzeum munkaterve nem csak a beérkezett anyagok gyüjtése, konzerválása és kiállítása, hanem elsősorban tudományos feldolgozása, rendszerbe foglalása és előkészítése úgy a centralizációra, mint az egyéni elmélyülésre és kutatásra.

A Múzeum szorosan együttmüködik a könyvtárral, mely tartalmazni fog minden kiadott eü. munkát és a honvédorvosi szolgálat munkáját, továbbá jellemző különálló munkákat, katonaorvosi kérdésekkel foglalkozó ki nem adott kéziratokat, plakátokat, rajzokat.

A Tudományos Rendelő és Múzeum a jó munka elvégzése érdekében a legszorosabb kapcsolatot veszi fel az osztályokkal. Az osztályvezetö orvos jelenti a Tudományos Rendelőnek az egyes érdekes kóresteket, melyet úgy vél, hogy a Múzeumba való, azonkívül a Tudományos Rendelő és Múzeum munkaterve szerint a vezető orvos naponta meglátogatja az egyes osztályokat és megbeszéli a vezető orvosokkal az általuk észlelt és a Múzeumba való eseteket.

Az anyagot az itt lévő káderek, úgy a szigorló orvosok, mint a középkáderek oktatásához fel kell használni" [14].

A Tudományos Rendelő és Múzeum tehát a gyógyítást, a kutatást és az oktatást támogató, a (katona)orvostudomány fejlesztésére, de ezzel egy időben tudománytörténeti feldolgozására is fókuszáló tárgyi, írásos és képi információforrásokat magában foglaló gyüjtemény (1.ábra).

Tanulságos röviden összevetni a gyüjtemény tervében foglaltakat az orvostudomány oktatásában és a tudományos munkában ma, a XXI. században használatos modern dokumentumokkal, szolgáltatásokkal. A kollekció tehát magában foglalta a betegdokumentációkat és leleteket, a vonatkozó szakirodalom bibliográfáit, statisztikákat, preparátumokat és képanyagot, tehát - mai kifejezésekkel behelyettesítve az olvasottakat - a gyakorlati gyógyító 
munka tapasztalatait, esetismertetéseket, szakirodalmi forrásokat, szakmai irányelveket, protokollokat, különféle technikájú illusztrációs anyagokat. Ilyen forrásokkal találkozhat a mai kutató, ha felkeresi a Clinical Key, az Up To Date, vagy folyamatosan gyarapodó magyar „testvérük”, a NOTA (Napivizit Orvosi Tudástár) honlapját, illetve belekattint a jelentős hazai és külföldi orvosi könyvkiadók e-könyv kínálatába; ezt a szerepet töltik be manapság a multimédiás oktatóanyagok és a 3D-s ábrázolások (2. árba), atlaszok online és offline változatai.

A technika ma már számunkra rendelkezésre áll, de az alapkoncepció - az MH EK történetére visszatekintve -, a Magyar Néphadsereg Központi Kórház Tudományos Rendelő és Múzeum, ennek tervezete, kiépítésének megindítása pedig az akkori parancsnok, Dr. Vadász Gyula orvos ezredes érdeme.

A Kórházban folyó tudományos munka információs hátterét érintő fejlesztési tervek megvalósítására azonban az évek során egyre kevesebb forrás állt rendelkezésre, 1956. április 19én Dr. Uray Gyula orvos ezredes, egészségügyi csoportfőnök levélben fordult Hazai Jenő vezérörnagy, politikai föcsoportfőnökhöz, melyben kifejtette, hogy a katonaorvosi kutatások „különösen a tömegpusztító fegyverek megjelenése folytán” egyre nagyobb fontossággal bírnak, a külföldi szakkönyvek és szakfolyóiratok beszerzési kerete azonban 1952 és 1956 között az egyötödére csökkent le. A korabeli belpolitikai helyzet ismeretében érthető, hogy még a megfogyatkozott kereten belüli is hatványozott arányban apadtak el a nyugati kiadványokra fordítható összegek, bár ez éppen ellentétes volt a védelem-politikai és -egészségügyi szempontokkal. „Ezért - olvasható a levélben - a sugárbiológiai kutatásokkal foglalkozó könyvek egyáltalán nem állnak rendelkezésünkre”. Emellett az egészségügyi csoportfőnök a külföldi tanulmányutak nagyobb mérvü támogatását is kérte, például állítva a hadvezetés elé a szocialista tábor országait: „tudomásunk van arról, hogy a szovjet és népi demokratikus katonaorvosok viszonylag gyakran és nagy számban járnak külföldi tanulmányutakra" - szól a megcáfolhatatlan érvelés [15].

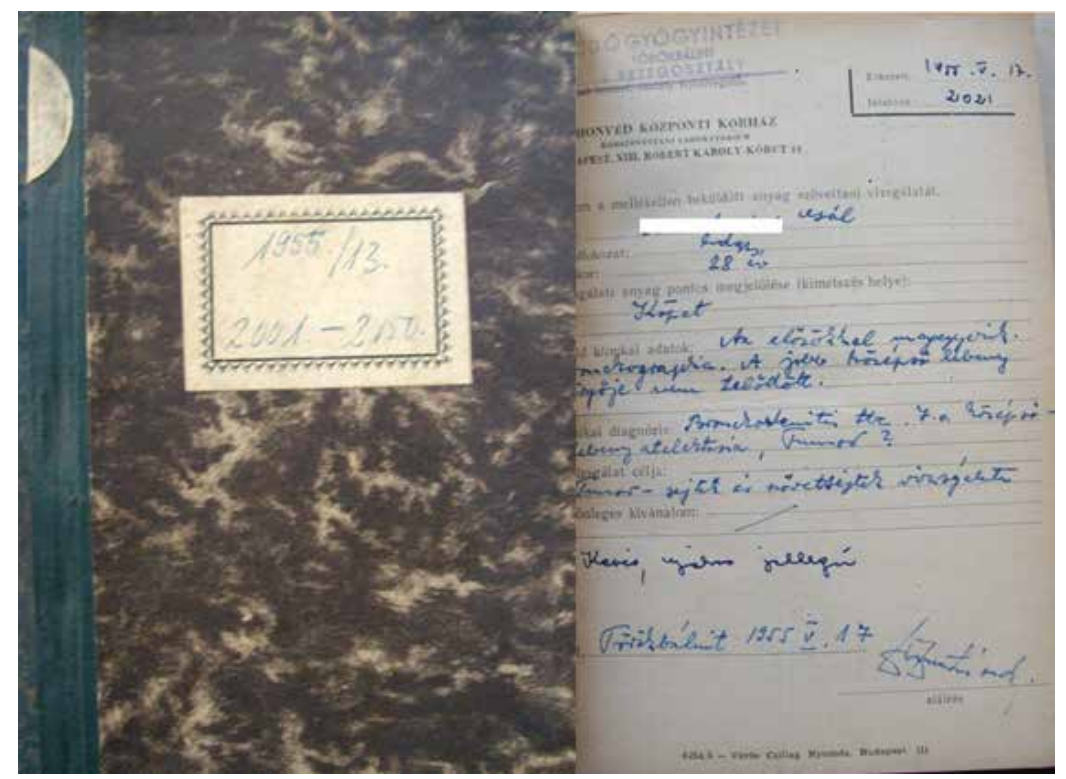

1. ábra. Patológiai vizsgálatkérő lapok és leletek egybekötött gyüjteménye 1955-böl, illetve egy vizsgálatkérö lap, a leletet a hátoldalára gépelték rá 

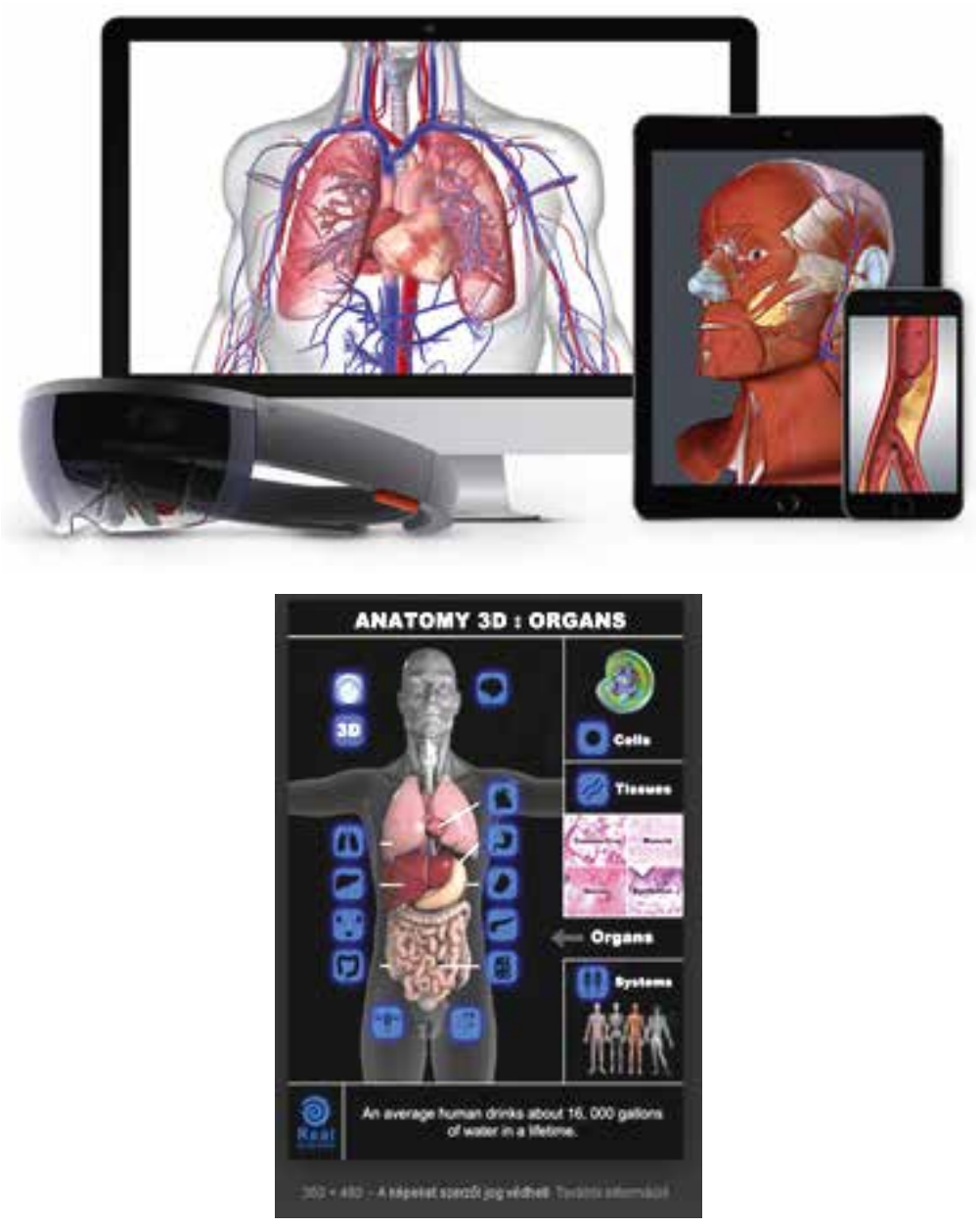

2. ábra. 3D anatómiai atlaszok (forrás: https://www.biodigital.com/ és https://www.pinterest.com/pin/501025527271339028)

A Kórház tudományos könyvtárára és a Tudományos Rendelő és Múzeumra fordítható pénzösszegek csökkenése végül ellehetetlenítette a komplex információs bázis müködését, az 1956 utáni napiparancsokban már nem található utalás a szervezeti egység létére. Mindazonáltal részleteiben a Honvédkórház folyosóin járva ma is láthatunk régi, a kórházban korábban használt orvosi eszközöket, a leletek, röntgen- és egyéb felvételek, betegdokumentációk megőrzésre kerülnek a MedWorks-ben, a Patológia osztály pedig vizsgálati eredményei, a boncolási és szövettani leletek mellett törvényi kötelezettségeinek megfelelően és lehetőségeinek keretei között megörzi a vizsgált szövetek paraffinos blokkjait, illetve a metszeteket tartalmazó tárgylemezeket. A szakirodalmi források pedig nyomtatott vagy elektronikus formában állnak rendelkezésre a Tudományos Könyvtárban.

A Tudományos Rendelő és Múzeum ma már ebben a formában nem létezik, de létjogosultsága, mindezen forrástípusok szükségessége most is megkérdőjelezhetetlen, egyes eszközei, feladatai más-más, modern formában élnek tovább, így figyelemreméltó e régi koncepció, a katonaorvosi kutatások és praxis történetének ezen kevéssé ismert momentuma. 


\section{Irodalom}

[1] Részletesebben vö. Pogányné Rózsa G.: Historia Domus : 1945-1950 : Források és adalékok a Magyar Honvédség Egészségügyi Központ Tudományos Könyvtára és a Honvédorvos címü szakfolyóirat történetéhez. In: Könyvtári Figyelö, 2018. 427-437.

[2] 116. sz. kórházparancsnoksági napiparancs. Bp., 1948. május 31. HM HIM Hadtörténelmi Levéltár [a továbbiakban: HL]. X. 5. 1948. Honvéd Központi Kórház.

[3] 68. sz. kórházparancsnoksági napiparancs. Bp., 1948. március 23.; 219. sz. kórházparancsnoksági napiparancs. Bp., 1948. szeptember 24. HL. X. 5. 1948. Honvéd Központi Kórház.; 1952. évi 2. sz. kórházparancsnoki napiparancs. Bp., 1952. január 3.; 1952. évi 253. sz. kórházparancsnoki napiparancs. Bp., 1952. október 27. ; HL. MN. 1952. MN. Központi Kórház. 102/03.; 1953. évi 246. sz. kórházparancsnoki napiparancs. Bp., 1953. október 21. HL. MN. 1953. MN. Központi Kórház. 102/03.

[4] 1953. évi 63. sz. kórházparancsnoki napiparancs. Bp., 1953. április 10. HL. MN. 1953. MN. Központi Kórház. 102/03.

[5] Nyíri É. - Fürész J.: MH EVI Tudományos Könyvtár. In: Honvédkórház kórháztörténet : 1899-1999 : jubileumi emlékkönyv. Honvéd Vezérkar Egészségügyi Csoportfőnökség, Bp., 1999. 197-201.

[6] 1953. évi 122. sz. kórházparancsnoki napiparancs. Bp., 1953. május 28. HL. MN. 1953. MN. Központi Kórház. 102/03.

[7] 06739/Htpszf. M.o.-1952. Bp., 1952. december 26. HL. X. 5. 1952/T. Honvéd Központi Kórház.

[8] 0300/1953. Bp., 1953. május 23. HL. MN. 1953/T. MN. Központi Kórház.

[9] 284. számú kórházparancsnoki napiparancs. Bp., 1948. december 11. HL. X. 5. 1948. Honvéd Központi Kórház.

[10] 1953. évi 97. sz. kórházparancsnoki napiparancs. Bp., 1953. április 27. HL. MN. 1953. MN. Központi Kórház. 102/03.

[11] 1951. évi 070. sz. titkos kórházparancsnoksági parancs. Bp., 1951. november 8. HL. MN. 1967/T. Központi Kórház.

[12] 1953. évi 171. sz. kórházparancsnoki napiparancs. Bp., 1953. július 25. HL. MN. 1953. MN. Központi Kórház. 102/03.

[13] Kivonat a Magyar Népköztársaság honvédelmi miniszterhelyettesének 01610 számú parancsából. Bp., 1953. november 12. HL. XIII. MN. 1953/T. Honvéd Egészségügyi Tudományos Kutató Intézet.

[14] 1952. évi 121. sz. kórházparancsnoki napiparancs. Bp., 1952. május 24. HL. MN. 1952. MN. Központi Kórház. 102/03.

[15] HM Egészségügyi Csoportfönökség 0157/1956. Bp., 1956. április 19. HL. MN. 1956/T. Központi Kórház. 